\title{
PENGARUH MODEL PEMBELAJARAN INKUIRI HIPOTETIK TERHADAP KETERAMPILAN BERPIKIR KRITIS DAN KETERAMPILAN PROSES SAINS SISWA SMP
}

\author{
KUSMIANTI \\ Fakultas Teknik UNMAS Denpasar PSDKU Mataram \\ e-mail: kusmianti67@gmail.com
}

\begin{abstract}
ABSTRAK
Tujuan penelitian ini adalah untuk menganalisis (1) perbedaan keterampilan berpikir kritis (KBK) dan keterampilan proses (KP) antara kelompok siswa yang belajar dengan model pembelajaran inkuiri hipotetik dan konvensional, (2) perbedaan keterampilan berpikir kritis (KBK) antara kelompok siswa yang belajar dengan model pembelajaran inkuiri hipotetik dan konvensional, (3) perbedaan keterampilan proses (KP) antara kelompok siswa yang belajar dengan model pembelajaran inkuiri hipotetik dan konvensional.

Penelitian ini merupakan kuasi eksperimen dengan rancangan factorial $2 \times 1$ posttest only control group design. Data KBK dikumpulkan melalui tes, data KP siswa dikumpulkan melalui tes dan observasi. Data yang diperoleh dianalisis secara 270tatistic deskriptif dan MANOVA satu jalur dengan hasil (1) terdapat perbedaan KBK dan KP siswa yang belajar dengan model inkuiri hipotetik dan model pembelajaran konvensional( $\mathrm{F}=59,161 ; \mathrm{p}<0,05)$, (2) terdapat perbedaan KBK siswa yang belajar dengan model inkuiri hipotetik dan konvensional ( $\mathrm{F}=22,219 ; \mathrm{p}<0,05)$, (3) terdapat perbedaan KP siswa yang belajar dengan model inkuiri hipotetik dan konvensional $(\mathrm{F}=113.559 ; \mathrm{p}<0,05)$
\end{abstract}

Keyword: inkuiri hipotetik, keterampilan berpikir kritis, keterampilan proses sains

\section{ABSTRACT}

The purpose of this research is to analyze: (1) the difference of critical thinking skills (CTS) and science process skills(SPS) between student's group who are managed with hypothetical inquiry model and conventional learning model, (2) the difference of critical thinking skills (CTS) between student's group who are managed with hypothetical inquiry model and conventional learning model, (3) the difference of science process skills (SPS) between student's group who are managed with hypothetical inquiry model and conventional learning model.

This research is quasi experiments with post-test only control group design factorial 2x1. Data of critical think skill are collected by using test and data of science process skillscollected by using test and observation. Data analyzed by using descriptive analyze and one way MANOVA.It is found: (1) there is significant difference of critical thinking skills (CTS) and science process skills(SPS) between student's group who are managed with hypothetical inquiry model and conventional learning model ( $F=59,161$; $p<0,05)$, (2) there is significant difference of critical thinking skills (CTS) between student's group who are managed with hypothetical inquiry model and conventional learning model( $F=22,219 ; p<0,05)$, (3) there is significant difference of science process skills (SPS) between student's group who are managed with hypothetical inquiry model and conventional learning model ( $F=113.559 ; p<0,05)$.

Keyword: hypothetical inquiry model, critical thinking skills, science process skills. 


\section{PENDAHULUAN}

\section{Latar Belakang}

Pendidikan merupakan sebuah proses yang akan membawa perbaikan bangsa.Melalui pendidikan diharapkan kualitas sumber daya manusia (SDM) di negara kita menjadi meningkat, maka orang-orang yang terlibat secara langsung maupun tidak langsung harus menyadari bahwa masa depan bangsa sangat ditentukan dengan kualitas pendidikan yang dilaksanakan (Basri, 2007). Tujuan pendidikan pada umumnya ialah menyediakan lingkungan yang memungkinkan anak didik untuk mengembangkan bakat dan kemampuan secara optimal sehingga ia dapat mewujudkan dirinya dan berfungsi sepenuhnya sesuai dengan kebutuhan pribadi dan kebutuhan masyarakat.

Berbagai upaya inovatif telah dilakukan oleh pemerintah untuk mencapai tujuan pendidikan. Upaya tersebut adalah melalui menyempurnakan kurikulum dari kurikulum 1994 hingga akhirnya sampai di KTSP. Kurikulum tingkat satuan pendidikan (KTSP) menuntut adanya perubahan pengajaran yang cenderung pasif dan teoritis serta berpusat pada guru menuju pada proses pembelajaran yang bersifat aktif, kreatif dan produktif. Hal ini mengacu pada permasalahan kontekstual dan berpusat pada siswa, sehingga siswa menemukan dan membangun pengetahuan sendiri. Perubahan paradigma dalam proses pembelajaran yang tadinya cenderung berpusat pada guru (teacher centered) menjadi pembelajaran yang berpusat pada siswa (learner centered) diharapkan dapat mendorong siswa untuk terlibat secara aktif dalam membangun pengetahuan, sikap dan perilaku (Harsono, 2004). Guru harus memberikan kebebasan siswa untuk belajar secara mandiri. Proses pembelajaran yang berpusat pada siswa, memberikan kesempatan dan fasilitas kepada siswa untuk membangun sendiri pengetahuannya, sehingga memperoleh pemahaman (understanding) yang mendalam dan pada akhirnya dapat meningkatkan kualitas belajar siswa.

Hakikat pembelajaran sains belum sepenuhnya terpenuhi. Hal ini dilihat dari berbagai fakta yang menunjukkan bahwa proses pembelajaran belum menggali secara maksimal kemampuan berpikir siswa serta keterampilan proses sains.Beberapa hasil penelitian yang menunjukkan hal tersebut diantaranya adalah hasil penelitian yang dilakukan Masfuah, et al. (2011) pada siswa kelas VII menyatakan bahwa siswa kurang berani bertanya atau mengemukakan pendapatnya saat pembelajaran berlangsung. Hal itu disebabkan karena siswa tidak terbiasa untuk berpikir secara kritis dan kurang terbiasa untuk mengungkapkan pendapatnya, selain itu sikap pasif yang diperlihatkan siswa disebabkan karena pelajaran fisika yang diajarkan merupakan sesuatu yang masih abstrak. Pembelajaran yang berlangsung tidak menghubungkan isi pembelajaran dengan kenyataan sehingga siswa kurang paham terhadap materi yang disampaikan. Kemampuan berpikir siswa direduksi dan sekedar dipahami sebagai kemampuan mengingat. Berdasarkan teori perkembangan menurut piaget, masa SMP merupakan masa transisi dari masa anak-anak. Mereka berpikir secara konkret menuju masa pubertas. Mereka dituntut untuk berpikir kritis, analitis, logis dan mampu memahami konsep secara abstrak dalam menyelesaikan permasalahan, sehingga guru memiliki peran sangat penting dalam pembelajaran. Guru harus mampu mengkondisikan agar anak dapat berpikir kritis, bersikap dan bertindak ilmiah. Pengajaran keterampilan berpikir kritis di Indonesia memiliki beberapa kendala, salah satunya adalah dominasinya guru dalam proses pembelajaran dan tidak memberi akses pada peserta didik untuk berkembang secara mandiri melalui penemuan dan proses berpikirnya (Trianto, 2007).Selain minimnya kemampuan siswa untuk menyelesaikan setiap permasalahan sains, keterampilan proses yang merupakan bagian dari kinerja ilmiah yang mengarah pada proses penemuan juga belum mendapat perhatian yang serius dari pendidikan. Kunandar (2007) menyatakan, bahwa pembelajaran harus lebih menekankan pada praktik,baik di laboratorium maupun di masyarakat, yang mengacu pada kemampuan kinerja ilmiah seseorang.

Melihat betapa pentingnya kinerja ilmiah tersebut seyogyanya kegiatan pembelajaran sains di kelas selalu menekankan pada kinerja ilmiah (proses). Kenyatannya, berdasarkan hasil penelitian yang dilakukan olehSadia, et al. (2003) menunjukkan bahwa 95\% tujuan pembelajaran khusus (TPK) yang dirancang guru fisika SMU di kabupaten Buleleng mengarah pada penguasaan produk sains dan hanya 5\% yang mengarah pada keterampilan proses sains. Metode yang digunakan oleh guru sains adalah metode ceramah (70\%), diskusi (10\%), demonstrasi (10\%), dan eksperimen (10\%). Kondisi yang demikian menyebabkan siswa lebih bersifat pasif dalam proses pembelajaran karena aktivitas siswa menjadi terbatas. Proses pembelajaran yang demikian secara tidak langsung menyebabkan keterampilan siswa tidak mampu berkembang secara optimal.

Bertitik tolak dari kesenjangan yang telah diuraikan di atas, maka perlu adanya penyempurnaan kegiatan pembelajaran. Penyempuranaan kegiatan belajar mengajar dapat dilakukan melalui penyempurnaan sumber belajar, suasana kelas, kurikulum, serta kemampuan dasar yang dimiliki guru.Pengembangan model pembelajaran yang lebih inovatif merupakan salah satu cara dalam meningkatkan kemampuan dasar guru dalam pembelajaran sains untuk mencapai tujuan pembelajaran yang diharapkan baik itu mampu 
mengembangkan keterampilan berpikir siswa serta keterampilan proses sains. Salah satu model pembelajaran yang tidak hanya memberdayakan sains sebagai produk tetapi juga mampu memberdayakan sains sebagai proses terutama demi peningkatan kemampuan berpikir kritis serta keterampilan proses sains yaitu model pembelajaran inkuiri hipotetik.

Secara konseptual model pembelajaran ini diyakini mampu melatih keterampilan berpikir dan keterampilan proses sains siswa. Inkuiri hipotetik berorientasi pada aktivitas kelas yang berpusat pada siswa dan memungkinkan siswa belajar memanfaatkan berbagai sumber belajar yang tidak hanya menjadikan guru sebagai satu-satunya sumber belajar. Terdapat tujuh tahap model pembelajaran inkuiri hipotetik yaitu 1) siswa mengungkapkan suatu permasalahan melalui kegiatan hand on, 2) siswa mengumpulkan data pengujian, 3) memformulasikan hipotesis berdasarkan data yang dikumpulkan dan kerangka berpikir siswa, 4) merancang dan melaksanakan eksperimen untuk validasi hipotesis, 5) mengumpulkan data dari eksperimen, 6) menginterpretasikan data yang diperoleh, 7) mengambil kesimpulan dari eksperiemen yang telah dilakukan dan membandingkan dengan hipotesis yang dibuat sebelumnya. Berdasarkan tahapan tersebut ditunjukkan bahwa siswa diberikan kesempatan berpikir tentang dunia sekitar yang secara aktif akan terlibat dalam proses mentalnya melalui kegiatan merumuskan masalah, berhipotesis, pengamatan, pengukuran dan pengumpulan data untuk menarik suatu kesimpulan.Belajar dengan model pembelajaran inkuiri hipotetik, siswa diibaratkan sebagai ilmuwan, di mana siswa diberi kebebasan untuk mengembangkan segala ide dan kemampuannya untuk menemukan sendiri pengetahuannya.Melalui inkuiri, siswa berpeluang untuk mengembangkan penalaran formalnya dengan baik sehingga akan mengasah kemampuan berpikir kritisnya sekaligus melatih keterampilan proses sains siswa.

\section{Tujuan Penelitian}

Penelitian ini memiliki tujuan untuk mengetahui : 1). perbedaan keterampilan berpikir kritis dan keterampilan proses antara siswa yang mengikuti pembelajaran dengan model inkuiri hipotetik dan siswa yang belajar dengan model pembelajaran konvensional,2). perbedaan keterampilan berpikir kritis antara siswa yang mengikuti pembelajaran dengan model inkuiri hipotetik dan siswa yang belajar dengan model pembelajaran konvensional,3). perbedaan keterampilan proses antara siswa yang mengikuti pembelajaran dengan model inkuiri hipotetik dan siswa yang belajar dengan model pembelajaran konvensional.

\section{METODE PENELITIAN}

Penelitian ini adalah penelitian eksperimen semu dengan rancangan postest only control group design. Desain penelitian disajikan pada Gambar 1.

Kelompok Eksperimen
Kelompok Kontrol

Gambar 1.Desain Penelitian Post-test Only Control Group Design

(dimodifikasi dari Sugiyono, 2008; Yount, 2006; Fisher \& Foreit, 2002)

Populasi penelitian ini adalah seluruh siswa kelas VII SMP N 1 Singaraja yang terdistribusi menjadi 10 kelas. Berdasarkan teknik random sampling terpilih kelas $\mathrm{VIIA}_{3}$ dan $\mathrm{VIIA}_{8}$ sebagai kelas eksperimen dengan jumlah siswa 54 orang yang mendapat perlakuan dengan model pembelajaran inkuiri hipotetik (MPIH) sedangkan kelas VIIA $_{4}$ dan VIIA 5 sebagai kelas kontrol dengan jumlah siswa 56 orang yang mendapat perlakuan dengan model pembelajaran konvensional (MPK). Data yang dikumpulkan dalam penelitian ini adalah keterampilan berpikir kritis (KBK) dan keterampilan proses sains (KP).

Kemampuan berpikir kritis diukur menggunakan tes yang terdiri dari 20 butir tes keterampilan berpikir kritis dalam bentuk pilihan ganda yang meliputi 5 aspek (1) interpretation, (2) analysis, (3) evaluation, (4) inference skills, dan (5) presenting arguments/explanation. Rentangan skor setiap butir tes adalah 0-1, sehingga skor maksimal 20. Data keterampilan proses sains diukur melalui test essay yang meliputi 6 aspek yaitu (1) merumuskan permasalahan, (2) merumuskan hipotesis, (3) menetapkan alat dan bahan, (4) menetapkan langkah kerja, (5) menganalisis data hasil percobaan, (6) menyimpulkan serta diukur menggunakan lembar observasi keterampilan proses yang meliputi3 aspek yaitu (1) menggunakan alat dan bahan, (2) mengumpulkan data, dan (3) mengkomunikasikan. 
Data dianalisis menggunakan analisis deskriptif dan MANOVA satu jalur. Sebelum dilakukan uji hipotesis menggunakan manova maka terlebih dahulu data penelitian harus memenuhi beberapa uji prasyarat yang meliputi uji normalitas sebaran data, uji homogenitas varians, uji homogenitas matrik varian dan uji kolinearitas. Uji normalitas sebaran data menggunakan statistik Kolmogorov-Smirnov dan Shapiro-Wilk, uji homogenitas varians menggunakan statistik Levene, uji homogenitas matrik varian menggunakan Box's $M$ testdan uji kolinearitas menggunakan korelasi product moment. Setelah memenuhi uji prasyarat tersebut maka dapat dilakukan uji hipoteisis yang mana uji hipotesis pertama menggunakan manova satu jalur, uji hipoteisis kedua dan ketiga menggunakan test of between-subjects effectskemudian dilanjutkan dengan uji LSD dengan taraf signifikansi $5 \%(\alpha=0,05)$ dan dianalisis dengan bantuan program SPSS 16.0 PC for Windowsuntuk mengetahui besar perbedaan.

\section{HASIL DAN PEMBAHASAN}

Hasil analisis deskriptif menunjukkan bahwa nilai rata-rata keterampilan berpikir kritis danketerampilan proses sains untuk siswa yang mengikuti pembelajaran dengan model inkuiri hipotetik lebih baik daripada siswa yang mengikuti pembelajaran menggunakan model pembelajaran konvensional. Hal ini dapat dilihat pada Tabel 1 berikut ini.

Tabel 1 Deskripsi Nilai Keterampilan Berpikir Kritis dan Keterampilan Proses

\begin{tabular}{|l|c|c|c|c|}
\hline \multirow{2}{*}{ Statistik } & \multicolumn{2}{|c|}{ KBK } & \multicolumn{2}{c|}{ MPIH } \\
\cline { 2 - 5 } & MPIH & MPK & 79.32 & MPK \\
\hline Mean & 57.13 & 47.95 & 79.5 & 67.54 \\
\hline Median & 57.5 & 50 & 79.5 & 69 \\
\hline Modus & 60 & 47.5 & 23 & 25 \\
\hline Jangkauan & 45 & 45 & 69 & 56 \\
\hline Nilai Minimum & 35 & 25 & 92 & 81 \\
\hline Nilia Maksimum & 80 & 70 & 5.67 & 5.91 \\
\hline Simpangan Baku & 1.05 & 9,94 & 32.11 & 35 \\
\hline Varians & 110 & 98.89 & & \\
\hline
\end{tabular}

Berdasarkan data yang ditunjukkan pada tabel 1 dapat dijabarkan dua hal yaitu pertama,nilai rata-rata KBK siswa yang mengikuti model pembelajaran inkuiri hipotetik ( $\bar{x})$ sebesar57,13 dengan standar deviasisebesar 1,05berada pada kategori cukupsedangkan nilai rata-rata KBK siswa yang mengikuti pembelajaran dengan model pembelajaran konvensional $(\overline{\mathrm{x}})$ sebesar47,95 dengan standar deviasi sebesar9,94berada pada kategori kurang. Hasil ini mengindikasikan bahwa secara deskriptif kualifikasi nilai rata-rata keterampilan berpikir kritis kedua kelompok adalah berbeda terlihat bahwa secara umum nilai ratarata keterampilan berpikir kritis siswa kelompok MPIH relatif lebih baik dibandingkan dengan kelompok MPK, namun walaupun demikianhasil penelitian ini menunjukkan nilai keterampilan berpikir kritis MPIH dan MPK belum mencapai standar keberhasilan yang memadai (hanya ber kualifikasi cukup kritis). Hal ini disebabkan karena untuk mengembangkan keterampilan berpikir kritis siswa memerlukan waktu yang cukup lama agar siswa betul-betul menguasai kemampuan yang sesuai dengan aspek keterampilan berpikir kritis.Perbandingan nilai rata-rata tes keterampilan berpikir kritis dalam bentuk grafik ditunjukkan pada Gambar 2.

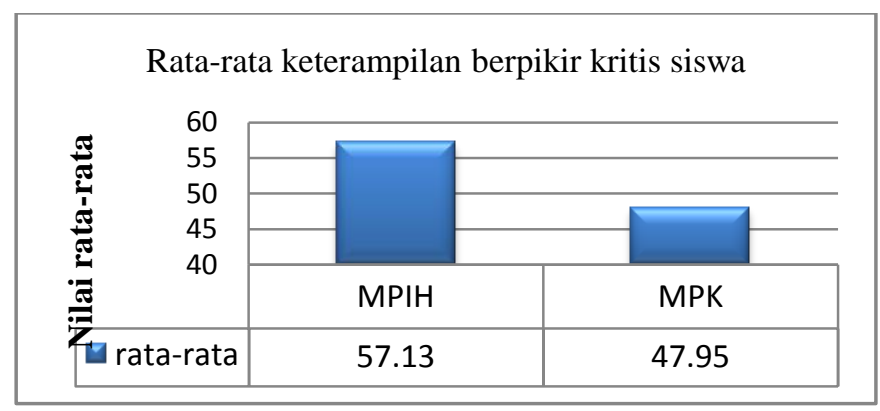

Gambar 2.Grafik Nilai Rata-rata Keterampilan Berpikir Kritis Siswa 
Kedua, Nilai rata-rata keterampilan proses sains siswa yang mengikuti model pembelajaran inkuiri hipotetik $(\bar{x})$ sebesar 79,32 dengan standar deviasisebesar5,67 berada pada kategori tinggi dan nilai rata-rata keterampilan proses sains siswa yang mengikuti model pembelajaran konvensional ( $\bar{x}$ )sebesar 67,54 dengan standar deviasisebesar 5,91 berada pada kategori cukup. Hasil ini mengindikasikan bahwa secara deskriptif kualifikasi nilai rata-rata keterampilan proses sains kedua kelompok berbeda. Secara umum nilai rata-rata keterampilan proses sains kelompok MPIH relatif lebih baik dibandingkan dengan kelompok MPK dalam mengembangkan keterampilan proses sains siswa. Perbedaan ini terlihat pada Gambar 3.

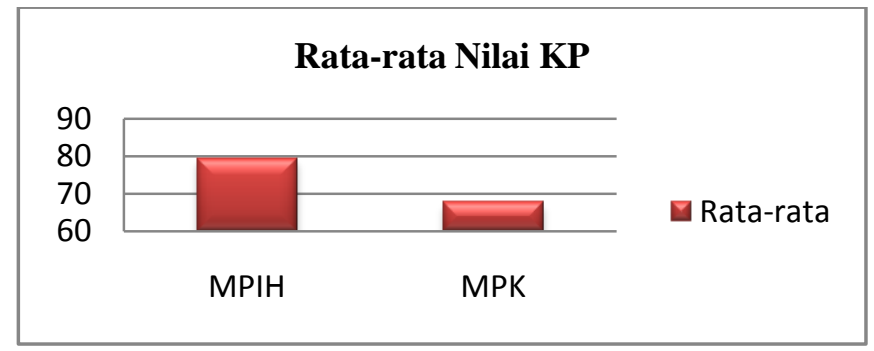

Gambar 3.Grafik Rata-rata Keterampilan proses sains siswa

Berdasarkan tes keterampilan berpikir kritis yang telah diberikan, diperoleh gambaran nilai rata-rata siswa pada masing-masing komponen seperti terlihat pada Tabel 2 dalam bentuk grafik dijabarkan pada Gambar 4.

Tabel 2. Nilai Rata-rata pada Masing-masing Komponen Keterampilan Berpikir Kritis

\begin{tabular}{|c|l|c|c|c|c|}
\hline \multirow{2}{*}{ No. } & KKomponen & \multicolumn{4}{|c|}{ Skor Rata-rata } \\
\cline { 3 - 6 } & KBK & MPIH & Kualifikasi & MPK & Kualifikasi \\
\hline 1 & Interpretasi & 68,98 & Cukup & 59,82 & Cukup \\
\hline 2 & Analisis & 60,74 & Cukup & 48,93 & Kurang \\
\hline 3 & Evaluasi & 53,70 & Cukup & 41,07 & Kurang \\
\hline 4 & Inferensi & 67,59 & Cukup & 45,09 & Kurang \\
\hline 5 & Eksplanasi & 40,7 & Kurang & 27,38 & Sangat Kurang \\
\hline
\end{tabular}

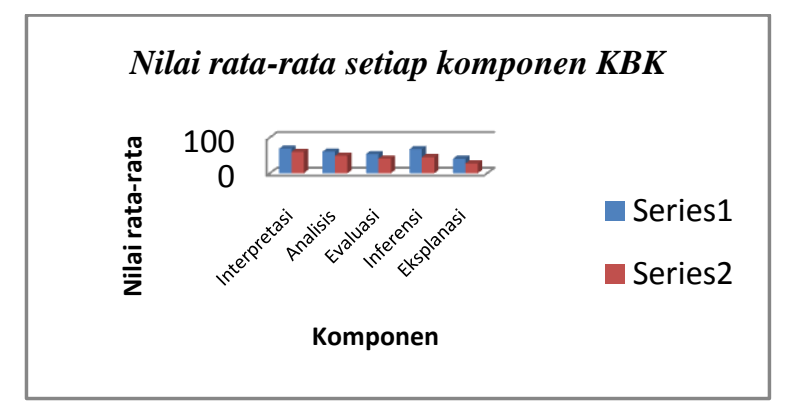

Gambar 4.Grafik Nilai rata-rata setiap komponen KB

Berdasarkan data hasil penelitian dapat dilihat bahwa aspek interpretasi memiliki nilai rata-rata paling tinggi dan eksplanasi memiliki nilai rata-rata paling rendah untuk model pembelajaran inkuiri hipotetik (MPIH) dan model pembelajaran konvensional (MPK). Hal tersebut diperoleh mungkin karena selama ini, dalam proses pembelajaran guru lebih menekankan pada siswa untukmemahami dan mengekspresikan makna dari suatu data atau kajian tertentu (interpretasi) dan kurang menekankan pada kemampuan dalam menyatakan dan menjabarkan hasil dari penalaran seseorang, menjustifikasi penalaran dari sisi konseptual, metodologis, dan kontekstual, serta mempresentasikan penalaran seseorang dalam bentuk argumen-argumen yang kuat (eksplanasi). Selain itu teknik penilaian yang sering digunakan di sekolah baik itu latihan soal maupun ulangan harian menggunakan tes pilihan ganda yang hanya menuntut jawaban tidak menuntut siswa untuk menjabarkan alasan mengapa mereka memilih jawaban tersebut. Hal ini berdampak pada siswa tidak terlatih dalam menjabarkan hasil pemikiran mereka sehingga memilih jawaban tersebut. Proses pembelajaran yang terjadi pada siswa lebih banyak menganalisis dan kemudian menginterpretasi hasil analisis tersebut pada pilihan yang ada. Kebiasaan tersebut kurang mengembangkan kemampuan siswa dalam memaparkan suatu argumen atau konsep yang dimiliki. Keterampilan proses sains siswa meliputi 9 aspek yaitu (1) 
merumuskan permasalahan, (2) merumuskan hipotesis, (3) menetapkan alat dan bahan, (4) menggunakan alat dan bahan, (5) menetapkan langkah kerja, (6) mengumpulkan data, (7) menganalisis data hasil percobaan, (8) menyimpulkan, dan (9) mengkomunikasikan. Berdasarkan tes dan hasil observasi keterampilan proses sains yang telah diberikan, diperoleh gambaran nilai rata-rata siswa pada masing-masing indikator seperti terlihat pada Tabel 3 dan dalam bentuk grafik terlihat pada Gambar 5.

Tabel 3. Nilai Rata-rata pada Masing-masing Indikator Keterampilan Proses Sains

\begin{tabular}{|c|l|c|c|c|c|}
\hline \multirow{2}{*}{ No. } & \multicolumn{2}{|c|}{ Indikator KP } & \multicolumn{4}{c|}{ Nilai Rata-rata } \\
\cline { 3 - 6 } & & MPIH & Kualifikasi & MPK & Kualifikasi \\
\hline 1 & Merumuskan Masalah & 78.7 & Tinggi & 67.41 & Cukup \\
\hline 2 & Mengajukan Hipotesis & 72.2 & Tinggi & 56.70 & Cukup \\
\hline 3 & Menetapkan Alat dan Bahan & 86.6 & Sangat Tinggi & 82.14 & Tinggi \\
\hline 4 & Menggunakan alat dan bahan & 75.5 & Tinggi & 69.64 & Tinggi \\
\hline 5 & Menetapkan Langkah Kerja & 81 & Tinggi & 67.86 & Cukup \\
\hline 6 & Mengumpulkan data & 82.4 & Tinggi & 61.61 & Cukup \\
\hline 7 & Menganalisis Data & 79.17 & Tinggi & 75.89 & Tinggi \\
\hline 8 & Menarik Kesimpulan & 76.39 & Tinggi & 61.16 & Cukup \\
\hline 9 & mengkomunikasikan & 81.48 & Tinggi & 66.07 & Cukup \\
\hline
\end{tabular}

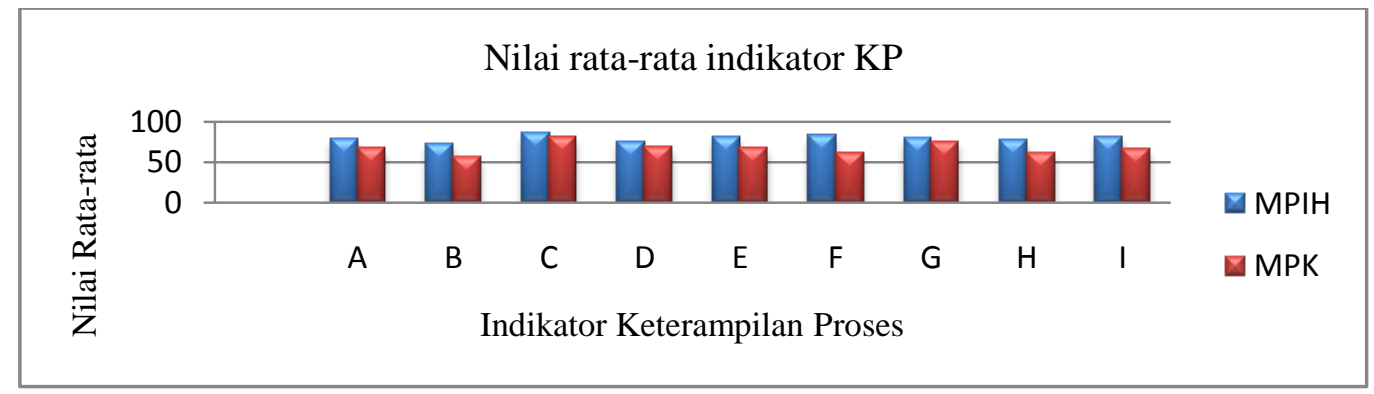

Gambar 5. Grafik Nilai rata-rata setiap komponen KP

Hasil keterampilan proses sains berdasarkan data yang diperoleh menunjukkan bahwa indikator yang memiliki nilai rata-rata terendah baik itu pada model pembelajaran inkuiri hipotetik maupun konvensional yaitu merumuskan hipotesis. Hasil pekerjaan siswa pada tes keterampilan proses yang menguji kemampuan merumuskan hipotesis kebanyakan siswa tidak mampu memaparkan hipotesis yang menunjukkan hubungan antar variabel secara singkat dan jelas.Kurangnya kemampuan ini mungkin disebabkan karena siswa tidak terbiasa dalam merumuskan sebuah hipotesis berdasarkan kegiatan preactivity, namun jika dibandingkan nilai rata-rata antara kedua model pembelajaran dapat dilihat bahwa nilai rata-rata yang diperoleh pada model pembelajaran inkuiri hipotetik lebih baik yaitu 72,2 daripada nilai rata-rata yang diperoleh pada model pembelajaran konvensional yaitu 56,7.

Sebelum melakukan pengujian hipotesis, terlebih dahulu dilakukan uji prasyarat mulai dari uji normalitas sebaran data. Uji normalitas dalam penilitian ini dilakukan dengan statistikKolmogorov-Smirnov test dan Shapiro-Wilktest dengan bantuan program SPSS Statistic 16.0.Kriteria pengujiannya adalah memiliki sebaran distribusi normal jika angka signifikansi yang diperoleh lebih besar 0,05 dan dalam hal lain sebaran tidak berdistribusi normal.Hasil ringkasan uji normalitas untuk keterampilan berpikir kritisdan keterampilan proses sainsdisajikan pada Tabel 4.

Tabel 4.Ringkasan Uji Normalitas Keterampilan berpikir kritisdan Keterampilan Proses

\begin{tabular}{|c|c|c|c|c|c|c|c|}
\hline & \multirow[b]{2}{*}{ MP } & \multicolumn{3}{|c|}{ Kolmogorov-Smirnov ${ }^{\mathrm{a}}$} & \multicolumn{3}{|c|}{ Shapiro-Wilk } \\
\hline & & Statistic & df & Sig. & Statistic & df & Sig. \\
\hline \multirow[t]{2}{*}{ KBK } & MPIH & 0.108 & 54 & 0.174 & 0.975 & 54 & 0.332 \\
\hline & MPK & 0.100 & 56 & $0.200^{*}$ & 0.976 & 56 & 0.338 \\
\hline \multirow[t]{2}{*}{ KP } & MPIH & 0.117 & 54 & 0.063 & 0.966 & 54 & 0.122 \\
\hline & MPK & 0.116 & 56 & 0.060 & 0.970 & 56 & 0.183 \\
\hline
\end{tabular}


Berdasarkan Tabel 4. diketahui bahwa untuk data keterampilan berpikir kritisdan keterampilan proses memiliki taraf signifikasi di atas 0,05. Hasil ini menunjukkan bahwa data tersebut berdasarkan dari populasi yang berdistribusi normal pada taraf signifikasi 0,05.Uji prasyarat selanjutnya yaitu uji homogenitas varian.

Uji homogenitas varian untuk keterampilan berpikir kritisdan keterampilan proses dilakukan dengan Levene's Test of Equality of Error Variance. Apabila signifikasi varian lebih besar daripada 0,05, maka varian yang ada adalah homogen. Ringkasan uji homogenitas varian dapat dilihat pada Tabel 5.

Tabel 5 .Uji Homogenitas Keterampilan berpikir kritisDan Keterampilan Proses Sains

\begin{tabular}{|ll|r|r|r|r|}
\hline & Levene Statistic & df1 & \multicolumn{1}{|c|}{ df2 } & \multicolumn{1}{c|}{ Sig. } \\
\hline KBK & Based on Mean & 0.128 & 1 & 108 & 0.721 \\
& 0.165 & 1 & 108 & 0.686 \\
& Based on Median & 0.165 & 1 & 107.979 & 0.686 \\
Based on Median and with & 0.129 & 1 & 108 & 0.720 \\
adjusted df & 0.088 & 1 & 108 & 0.767 \\
Based on trimmed mean & 0.042 & 1 & 108 & 0.838 \\
KP $\quad$ Based on Mean & 0.042 & 1 & 105.831 & 0.838 \\
Based on Median & 0.089 & 1 & 108 & 0.766 \\
Based on Median and with & & &
\end{tabular}

Tabel 5.menunjukkan bahwa nilai-nilai statistik Levene menunjukkan angka signifikansi $p>0,05$. Hal ini menunjukkan bahwa varian antar kelompok model pembelajaran adalah sama (homogen), baik untuk variabel keterampilan berpikir kritis (KBK) maupun variabel keterampilan proses sains (KP).

Uji homogenitas matriks varians antar variabel dependen menggunakan Box's $M$ test dengan bantuan program SPSS 16.0 for Windows. Matriks varian variabel terikat akan sama jika signifikansi pada uji Box's M lebih besar daripada 0,05 (Santoso, 2010). Hasil uji homogenitas matriks varians-kovarians disajikan pada Tabel 6.

Tabel 6.Box's M Test untuk Pengujian Kesamaan Matriks Varians

\begin{tabular}{|l|r|}
\hline Box's M & 1.070 \\
\hline F & 0.350 \\
\hline df1 & 3 \\
\hline df2 & $2.194 \mathrm{E} 6$ \\
\hline Sig. & 0.789 \\
\hline
\end{tabular}

Berdasarkan Tabel 6. tampak bahwa nilai $F=0,350$ dengan signifikansi $p>0,05$ yakni 0,789 . Ini berarti bahwa matriks varians antar variabel keterampilan berpikir kritis dan keterampilan proses sains adalah sama (homogen).

Ujikorelasi antar variabel dependen dimaksudkan untuk mengetahui apakah terdapat korelasi antara variabel dependen. Kolinieritas dapat diuji dengan korelasi product moment. Hasil uji korelasi antar variabel dependen dapat dapat disajikan dalam Tabel 7.

Tabel 7.Korelasi antar Variabel Bebas Keterampilan berpikir kritis (KBK) dan Keterampilan Proses (KP)

\begin{tabular}{|ll|r|r|}
\hline & & KBK & \multicolumn{1}{|c|}{ KP } \\
\hline KBK & Pearson Correlation & 1 & $0.436^{* *}$ \\
& Sig. (2-tailed) & & 0.000 \\
& N & 110 & 110 \\
\hline KP & Pearson Correlation & $0.436^{* *}$ & 1 \\
& Sig. (2-tailed) & 0.000 & \\
\hline
\end{tabular}


Berdasarkan hasil korelasi tersebut maka didapatkan nilai korelasi antar variabel dependen sebesar 0,436menunjukkan $r_{\text {hitung }}<0,8$ dan Sig. (2-tailed) $<0,05$ berarti bahwa variable keterampilan berpikir kritis dan keterampilan proses tidak kolinier. Setelah semua uji prasyarat terpenuhi maka analisis dilanjutkan dengan uji hipotesis menggunakan MANOVA satu jalur.Hasil analisis uji hipotesis dapat disajikan pada Tabel 8.

Tabel 8. Ringkasan Hasil Uji Multivariat

\begin{tabular}{|ll|r|r|r|r|r|}
\hline Effect & & Value & \multicolumn{1}{|c|}{$\mathrm{F}$} & Hypothesis df & Error df & \multicolumn{1}{c|}{ Sig. } \\
\hline Intercept & Pillai's Trace & 0.994 & $9.0593^{\mathrm{a}}$ & 2.000 & 107.000 & 0.000 \\
& Wilks' Lambda & 0.006 & $9.059 \mathrm{E} 3^{\mathrm{a}}$ & 2.000 & 107.000 & 0.000 \\
& Hotelling's Trace & 169.330 & $9.059 \mathrm{E} 3^{\mathrm{a}}$ & 2.000 & 107.000 & 0.000 \\
& Roy's Largest Root & 169.330 & $9.059 \mathrm{E} 3^{\mathrm{a}}$ & 2.000 & 107.000 & 0.000 \\
\hline MP & Pillai's Trace & 0.525 & $59.161^{\mathrm{a}}$ & 2.000 & 107.000 & 0.000 \\
& Wilks' Lambda & 0.475 & $59.161^{\mathrm{a}}$ & 2.000 & 107.000 & 0.000 \\
& Hotelling's Trace & 1.106 & $59.161^{\mathrm{a}}$ & 2.000 & 107.000 & 0.000 \\
& Roy's Largest Root & 1.106 & $59.161^{\mathrm{a}}$ & 2.000 & 107.000 & 0.000 \\
\hline
\end{tabular}

Berdasarkan hasil uji multivariat seperti yang disajikan pada Tabel 8. dapat ditarik interpretasiinterpretasi yaitu diperoleh nilai-nilai statistik Pillai's Trace,Wilk's Lambda, Hotelling's Trace, dan Roy's Largest Root masing-masing dengan $\mathrm{F}=59,161$ dan angka signifikansi kurang dari $0,05(\mathrm{p}<0,05)$ menunjukkan bahwa terdapat pengaruh model pembelajaran terhadap keterampilan berpikir kritis dan keterampilan proses sains.

Pengujian hipotesis kedua dengan test of between-subjects effects. Hipotesis yang diuji secara statistik adalah $\mathrm{H}_{0}$. Kriteria penolakan $\mathrm{H}_{0}$ jika harga $\mathrm{F}$ memiliki angka signifikansi lebih kecil dari 0,05. Rekapitulasi hasil test of between-subjects effectsBerdasarkan hasil perhitungan analisis varian dengan menggunakan SPSS disajikan pada Tabel 9.

Tabel 9. RekapitulasiHasil Test of Between-Subjects Effects

\begin{tabular}{|c|c|c|c|c|c|c|}
\hline Source & $\begin{array}{l}\text { Dependent } \\
\text { Variable }\end{array}$ & \begin{tabular}{|c|} 
Type III Sum of \\
Squares
\end{tabular} & $\mathrm{df}$ & Mean Square & $\mathrm{F}$ & Sig. \\
\hline \multirow{2}{*}{$\begin{array}{l}\text { Corrected } \\
\text { Model }\end{array}$} & KBK & $2318.341^{\mathrm{a}}$ & 1 & 2318.341 & 22.219 & 0.000 \\
\hline & $\mathrm{KP}$ & $3814.287^{\mathrm{b}}$ & 1 & 3814.287 & 113.559 & 0.000 \\
\hline \multirow{2}{*}{ Intercept } & KBK & 303526.523 & 1 & 303526.523 & $2.909 \mathrm{E} 3$ & 0.000 \\
\hline & KP & 592843.596 & 1 & 592843.596 & $1.765 \mathrm{E} 4$ & 0.000 \\
\hline \multirow[t]{2}{*}{ MP } & KBK & 2318.341 & 1 & 2318.341 & 22.219 & 0.000 \\
\hline & KP & 3814.287 & 1 & 3814.287 & 113.559 & 0.000 \\
\hline \multirow[t]{2}{*}{ Error } & KBK & 11268.932 & 108 & 104.342 & & \\
\hline & KP & 3627.577 & 108 & 33.589 & & \\
\hline \multirow[t]{2}{*}{ Total } & KBK & 316250.000 & 110 & & & \\
\hline & KP & 598753.000 & 110 & & & \\
\hline \multirow{2}{*}{$\begin{array}{l}\text { Corrected } \\
\text { Total }\end{array}$} & KBK & 13587.273 & 109 & & & \\
\hline & $\mathrm{KP}$ & 7441.864 & 109 & & & \\
\hline \multicolumn{4}{|c|}{ a. R Squared $=.171($ Adjusted R Squared $=.163)$} & & & \\
\hline \multicolumn{4}{|c|}{ b. R Squared $=.513($ Adjusted R Squared $=.508)$} & & & \\
\hline
\end{tabular}

Berdasarkan rekapitulasi hasil test of between-subjects effects yang disajikan pada Tabel 4.15, dapat diinterpretasikan bahwa pengaruh model pembelajaran terhadap keterampilan berpikir kritis siswa, ditunjukkan dengan harga statistik F sebesar 22,219dengan angka signifikansi kurang dari 0,05 sehingga $\mathbf{H}_{\mathbf{0}}$ ditolak. Jadi, terdapat perbedaan keterampilan berpikir kritis antara kelompok siswa yang belajar dengan model pembelajaran inkuiri hipotetik dan model pembelajaran konvensional.Hasil ini diperkuat dengan hasil 
LSD yang menunjukkan bahwa model pembelajaran inkuiri hipotetik lebih unggul dibandingkan dengan model pembelajaran konvensional dalam keterampilan berpikir kritis dan keterampilan proses sains. Perbedaan nilai rata-rata pasangan model pembelajaran inkuiri hipotetik dengan konvensional dengan metode Least Significant Differnce (LSD) untuk taraf signifikansi $\alpha=0,05$ diperoleh nilai $\mathrm{t}_{(0,025 ; 108)}=1,980$ dan batas penolakan LSD $=3,856$ sementara itu perbedaan nilai rata-rata keterampilan berpikir kritis siswa MPIH dan MPK adalah $\Delta \mu=[\mu(\mathrm{MPIH})-\mu(\mathrm{MPK})]$ sebesar 9,183. Nilai $\Delta \mu$ lebih besar daripada batas penolakan LSD. Jadi, skor rata-rata keterampilan berpikir kritis siswa kelompok MPIH dan MPK berbeda secara signifikan pada taraf signifikansi 0,05 .

Pengujian hipotesis ketiga berdasarkan rekapitulasi hasil test of between-subjects effects, dapat diinterpretasikan bahwa pengaruh model pembelajaran terhadap keterampilan proses sainssiswa, ditunjukkan dengan harga statistik $\mathrm{F}$ sebesar 113.559 dengan angka signifikansi kurang dari 0,05 sehingga $\mathbf{H}_{\mathbf{0}}$ ditolak.Jadi, dapat disimpulkan bahwa terdapat perbedaan keterampilan proses sains antara kelompok siswa yang belajar dengan model pembelajaran inkuiri hipotetik dan model pembelajaran konvensional. Hasil ini diperkuat dengan metode Least Significant Differnce $(L S D)$ Untuk taraf signifikansi $\alpha=0,05$, diperoleh nilai statistik tabel $=\mathrm{t}_{(0,025 ; 108)}=1,980$. dan batas penolakan adalah LSD $=2,189$ sementara itu perbedaan nilai rata-rata keterampilan proses sains siswa MPIH dan MPK adalah $\Delta \mu=[\mu(\mathrm{MPIH})-\mu(\mathrm{MPK})]$ sebesar 11,779 dengan simpangan baku 1,105dan angka signifikansi kurang dari 0,05 . Nilai $\Delta \mu$ lebih besar dari pada penolakan LSD. Jadi, nilai rata-rata keterampilan proses sains siswa kelompok MPIH dan MPK berbeda secara signifikan pada taraf signifikansi 0,05 . Hasil pengujian hipotesis itu menunjukkan bahwa terdapat perbedaan keterampilan berpikir kritis dan keterampilan proses sains yang signifikan antara kelompok siswa yang belajar dengan model pembelajaraninkuiri hipotetik dan kelompok siswa yang belajar dengan model pembelajaran konvensional dengan nilai $\mathrm{F}=59,161$ dimana $\mathrm{p}<0,05$. Model pembelajaran inkuiri hipotetik mampu memberikan nilai keterampilan berpikir kritis dan keterampilan prosessains yang lebih baik dibandingkan dengan MPK. Hal ini sesuai dengan kajian teori yang menyatakan inkuiri merupakan salah satu model pembelajaran yang inovatif yang tepat digunakan dalam pembelajaran sains khususnya fisika karena dapat mengembangkan kemampuan siswa untuk memahami dan memperoleh pengetahuan melalui cara berfikir sistematis dan ilmiah. Inkuiri lebih mengutamakan aktivitas siswa dalam proses kegiatan pembelajaran yang mana siswa membangun pengetahuan dan pemahaman tentang bagaimana seorang ilmuwan bekerja.Masing-masing level inkuiri tersebut mencakup keterampilan intelektual dan keterampilan proses sains (wenning, 2005).

Model pembelajaran ini dapat meningkatkan keterampilan berpikir kritis siswa karena siswa terbiasa dalam mengkaji suatu permasalahan melalui kegiatan hand on yang kemudian di analisis melalui kajian teori untuk merumuskan suatu hipotesis dan diuji melalui sebuah praktikum hingga mendapatkan sebuah kesimpulan. Siswa berperan sebagai seorang ilmuwan untuk memperoleh suatu fakta melalui pengalaman yang hasilnya dikomunikasikan kepada siswa lainnya. Pola pembelajaran tersebut juga akan membiasakan siswa untuk mengembangkan keterampilan proses sains.

Berdasarkan penelitian iniketerampilan berpikir kritisdan keterampilan proses sains siswa dapat ditingkatkan dengan menerapkan model pembelajaran inkuiri hipotetik. Implikasi temuan hasil penelitian ini adalah pertama, model pembelajaran inkuiri hipotetik dapat diterapkan sebagai alternatif fasilitas belajar untuk mencapai keterampilan berpikir kritis dan keterampilan proses fisika secara optimal dalam pembelajaran fisika di SMP. Pembelajaran inkuiri hipotetik dapat diimplementasikan melalui penyelidikan ilmiah. Sebagai konsekuensinya, pihak sekolah lebih mengoptimalkan fasilitas laboratorium, agar dapat mendukung proses pembelajaran dengan kegiatan eksperimen secara optimal. Kedua, hasil penelitian menunjukkan bahwa model pembelajaran inkuiri hipotetikbaik diterapkan untuk mengembangkan keterampilan berpikir kritis dan keterampilan proses fisika. Hal tersebut disebabkan karena model pembelajaran inkuiri hipotetikmenekankan pada penyelidikan ilmiah yang memerlukan pengetahuan awal siswa. Sebagai konsekuensinya, proses pembelajaran di sekolah seyogyanya didasarkan pada pengalaman siswa.

\section{SIMPULAN DAN SARAN}

\section{Simpulan}

Berdasarkan hasil penelitian dapat disimpulankan sebagai berikut.

1. Terdapat perbedaan keterampilan berpikir kritis dan keterampilan proses fisika antara kelompok siswa yang belajar dengan model pembelajaran inkuiri hipotetik dan konvensional $(F=59,161 ; p<0,05)$.

2. Terdapat perbedaan signifikan variabel model pembelajaran terhadap $\mathrm{KBK}(\mathrm{F}=22.219 ; \mathrm{p}<0,05)$.

3. Terdapat perbedaan signifikan variabel model pembelajaran terhadap $\mathrm{KP}(\mathrm{F}=113.559 ; \mathrm{p}<0,05)$. 


\section{Saran-saran}

1. Model pembelajaran inkuiri hipotetik adalah model pembelajaran yang lebih menekankan pada pengkonstruksian pengetahuan melalui investigasi, yang dapat memberikan peluang pada pencapaian keterampilan berpikir kritis dan keterampilan proses siswa sehingga disarankan guru lebih baik mengutamakan eksplorasi pengalaman siswa terlebih dahulu sehingga konstruksi pemahaman siswa menjadi lebih kuat.

2. Model pembelajaran inkuiri hipotetik lebih unggul pada semua aspek keterampilan berpikir kritis dan keterampilan proses namun karena waktu yang terbatas maka keterampilan berpikir kritis dan keterampilan proses belum maksimal dikembangkan sehingga diharapkan guru secara kontinu menerapkan model pembelajaran inovatif ini.

3. Pada proses pembelajaran diharapkan guru lebih menekankan aspek eksplanasi dan merumuskan hipotesis pada siswa sehingga siswa terbiasa memaparkan hasil dari penalaran atau mempresentasikan hasil penalaran dalam bentuk argumen-argumen yang kuat. Hal ini disebabkan karena berdasarkan hasil penelitian diperoleh bahwa dari 5 aspek keterampilan berpikir kritis ternyata aspek eksplanasi menunjukkan nilai rata-rata terkecil baik itu menggunakan model pembelajaran inkuiri hipotetik maupun model pembelajaran konvensional. Pada keterampilan proses diperoleh nilai rata-rata terkecil pada kedua model pembelajaran yaitu aspek merumuskan hipotesis.

\section{DAFTAR PUSTAKA}

Basri, H. 2007. Menuju “Dark Age" Pendidikan Indonesia. Artikel.

Ennis, R. H. 1985. Goal Critical Thinking Curriculum. Dalam Costa, A. L. (Ed): Developing minds: a resourse book for teaching thinking. Alexandria, Virginia: Association for Supervision and Curriculum Developing (ASCD), 54-57.

Kunandar. 2007. Guru Profesional Implementasi Kurikulum Tingkat Satuan Pendidikan (KTSP) dan Sukses dalam Sertifikasi Guru. PT. Raja Grafindo Persada Jakarta.

Masfuah, S., Rusilowati, A., Sarwi. 2011. Pembelajaran Kebencanaan Alam dengan Model Bertukar Pasangan Bervisi Sets untuk Menumbuhkan Kemampuan Berpikir Kritis Siswa. Jurnal Pendidikan Fisika Indonesia. 115-120.

Sugiyono. 2008. Metode Penelitian Pendidikan (Pendekatan Kuantitatif, Kualitatif dan R\&D). Alfabeta. Bandung

Trianto. 2007. Model-model Pembelajaran Inovatif Berorientasi Konstruktivistik.Prestasi Pustaka. Surabaya

Wenning, C. 2005. Implementing Inquiry Based Instruction in the Science Classroom: A New Model for Solving the Improvement of Practice Problem. Journal Physics Teacher Education Online. 2(4). 915 